\title{
THE REIGN OF ALEXANDER OBRENOVIĆ IN THE REFLECTION OF THE RUSSIAN PRESS
}

\author{
Victor E. Tumanin ${ }^{1}$ \\ Marat Z. Galiullin ${ }^{2}$ \\ Denis R. Sharafutdinov ${ }^{3}$
}

Abstract: April 1, 1893, the sixteenyear-old King of Serbia, Alexander Obrenović, made a coup d'état [1]. On the direct instructions of his father, Milan Obrenović, who lived after his abdication in France, minor Alexander Obrenovićh arrested the regents J. Ristić, K. Protić and J. Belimarcović, sent ministers in prison, declared himself an adult and took power into his own hands. [2] The events of 1893 became a new stage in the difficult period of the development of the independent Serbian state at the turn of the 19th and 20th centuries; that period is of particular interest to researchers $[3,16,17]$. The events that the contemporaries called "the Serbian revolution" were discussed in the European press solely from the point of view of practical expediency, and therefore even the most cautious contemporaries were inclined to see the latent participation of Russian diplomacy in it. The English "Times" decided that the "act" of the king is "although not constitutional", but "natural" [4]. The representatives of the press in other European capitals (Berlin, Vienna and Paris newspapers) agreed with the opinion of the newspaper which sympathized with the liberation of Serbia from the "imaginary liberal terror" and the " bold move " of the king who put an end to the protracted crisis, the way out could not be peaceful, in their opinion [5]. It was not without curiosity: "Daily News" of Gladstone launched a malicious wickedness around the world calling the April events in Belgrade "a wedding gift to Knyaz Saxe-Coburg" [4]. The coup d'etat á la Alexandre de

\footnotetext{
${ }^{1}$ Kazan Federal University, Institute of International Relations, History and Oriental Studies. e-mail: $\underline{\text { v. }}$ tumanin@mail.ru. Tel. : +79172300606

${ }^{2}$ Kazan Federal University, Institute of International Relations, History and Oriental Studies. e-mail: $\underline{\mathrm{v}}$. tumanin@mail.ru. Tel. : +79172300606

${ }^{3}$ Kazan Federal University, Institute of International Relations, History and Oriental Studies. e-mail: $\underline{\mathrm{v}}$. tumanin@mail.ru. Tel. : +79172300606
} 
Serbie was a household name for a long time.

Keywords: history, international relations, Europe, Serbia, Russia, Austria, the Balkans.

\section{Introduction}

In the understanding of the Russian public, the Balkan Peninsula was "a delicate place on the map, because every revolution there affects all of Europe" [4], therefore, most Russian observers assessed the accomplished coup d'état in terms of the "alleged interests of national politics", i. e. its consequences for Russia [6].

Only a small number of publications, among them "The Northern Bulletin" and the "Bulletin of Europe", tried to give an unbiased analysis of the Serbian events. The most cautious part of the publications, for example, the "Bulletin of Europe", not knowing full information about the true causes of the coup, were careful not to comment on the actions of the Regency and the government, and therefore the pages of the Russian press were filled with inconsistencies and uncertainty, and the assessment of Serbian events was blurred: "In Serbia everything is all right, except for temporary mistakes, fascinations and misunderstandings" [5] On the one hand, the young king was difficult to suspect in the Austrofil moods; the friendly disposition towards Russia prevailed in Serbia, its pro-Russian sympathies were officially recognized. J. Ristić, who was left at a loose end, was also listed as a friend of Petersburg; he was often criticized abroad as "pan-Slavist" [5].

Also it was not clear for contemporaries why Alexander Obrenović, having shown in the course of the coup the strength and determination of character, as well as the politically mature mind, did not show himself until April 1893. The conclusion was that it was obviously led by someone else and by more experienced hand [5].

After the ex-King Milan returned to Belgrade, despite the official ban, in the Serbian foreign policy "the west wind blew strongly", as the Russian contemporaries put it [7]. Like his father, the young king was guided in foreign policy by Austria-Hungary. The turn towards Vienna became noticeable literally from the first steps of the "new full king" and found its expression primarily in the proclamation of Alexander to the Serbian people and the 
program of Dokić, which followed it; in both documents a rather contradictory position was expressed: along with the arguments about commitment to the "national idea" and the maintenance of "peace with all powers", a mention was made of the conclusion of a new trade agreement with Austria [4].

\section{METHODS}

The research is based on reliable sources and an extensive historiographic base. First of all, among the sources are the "Severny Vestnik" and "Russky Vestnik" published at the end of the 19th and the beginning of the 20th century, and the materials from such periodicals as "Vestnik Evropy" and "Nablyudatel".

The research is based on the following principles: scientific character, i.e. drawing conclusions based on an analysis of the full range of documents and scientific literature and taking into account all events and phenomena in them; impartiality, i.e. on a characteristic of the events and phenomena of the historical process under study without any preference on the part of the researcher; systemacity, i.e. taking into account the variety of factors that affect the historical process, such as objective and subjective, domestic and foreign policy, as well as local and global factors; historicism, i.e. on the consideration of historical processes and phenomena in their constant development and modification.

The presentation of the material was constructed according to the subject and chronological principle.

The historical-genetic method also used in the work provided an opportunity to reveal the general course of events. This method helped to identify the cause and effect relationships between the main economic and political problems of Serbia.

Concrete historical analysis allowed us to consider events and phenomena in the context of the corresponding epoch, when the evaluation of events is given from the point of view of a specific historical situation.

The study has also used a historical and systematic approach. The systematic nature of socio-historical development means that all events, situations and processes of this development are conditioned and have a causal relationship, and are interconnected functionally. 


\section{Results}

In the conservative media, doubts have given way to the conviction that the young King Alexander himself is "a submissive tool, a simple sign to divert one's eyes from the actual seizure of power by Milan Obrenović" [8]. Returning to Serbia and taking over the post of commander-in-chief of the Serbian army, the father of the ruling monarch was equally autocratic in controlling the external affairs of the country.

Having asked about the reasons for the return of the ex-king, the observer questioned the popular opinion that it was dictated by "only the pursuit of profit" [8].

Already in the autumn of 1894 the European press reported on the intention of the king to visit Budapest, Vienna and Berlin, allegedly with a view to soliciting the entry of Serbia into the Triple Alliance. An observer from "Russky vestnik" who was not inclined to trust news from "idle gossips of Central European newspapers", however, found that the some accuracy is given to it by the internal situation in Serbia, which "was something wrong". The radical Serbian newspaper "Od'ek" saw in this rapprochement a particular danger, believing that "Austria, apparently, wants to separate the king from the people" [8].

Immediately after the coup, Alexander Obrenovićh decided to make a visit to Constantinople as a matter of priority. The young monarch has motivated his decision to visit the Turkish sultan by the fact that "it was natural for my father and me to visit the sultan before other sovereigns. Strengthening of good relations between Serbia and Turkey is one of our main tasks" [8]. The correspondent also noted that in a conversation with him, the king often referred to the example of Bulgaria, not wishing, apparently, that the Bulgarian government would gain more mercy in Constantinople. At the conclusion of his communication with the press representative, Alexander found it necessary to add about his desire to establish the best relations between Serbia and Austria-Hungary: "We need, and we will need Austria", he said [7].

Contemporaries once again convinced in this due to the behavior of the young king, who continued to actively establish relations with AustriaHungary and Germany: after his trip to Pest, where he met Franz Josef and the foreign minister Kalnaki, specially 
summoned from Vienna, and then to Berlin where he attended the ceremony of consecration and distribution of the banners to the new battalions; at the same time Emperor Wilhelm granted Alexander Obrenović the Order of the Black Eagle [9], what drew the attention of the European public and gave rise to rumors about Serbia's accession to the Triple Alliance. This was all the more likely that the young king was correlated with his father's active recommendations. According to Russian observers, two facts were against this assumption: firstly, the deplorable state of Serbian troops and the financial system and, secondly, even before the trip to Pest, there were trips to Constantinople and St. Petersburg [9].

And if the visit of Alexander Obrenović to the capital of the Ottoman Empire seemed to contemporaries (both Russian and European) as "a rather unexpected trip", the visit to AustriaHungary was very predictable.

An example was also the unpleasant incident that occurred during the celebration of the Millennium of Hungary, which almost led to the diplomatic conflict. Analyzing the position of Serbia in the context of the foreign policy situation, the Austrian-
200

Hungarian Minister of Foreign Affairs Count A. Golukhovsky found that it "can not be considered satisfactory" [10]. Serbia "could be considered an exemplary state", at present the country "is divided to such an extent due to the struggle of parties, and its situation is so unstable that its friends can see with great regret that this instability is increasing more and more". Moreover, "in Belgrade, they were inclined to blame their own mistakes on others," not realizing that "such behavior can create a great danger to the interests of the kingdom itself".

In the opinion of contemporaries, "Austrian politics, being such unceremonious and in such a patronizing tone referring to its Slavonic neighbors, achieves results which were directly opposite to those it would like to achieve" [10]. This policy equally irritated Serbs, Bulgarians and Romanians and thereby brought them closer together. An observer pointed to the latter fact as a steady trend of rapprochement between the Bulgarians and Serbs; between the two fraternal peoples "the most cordial relations began", what was expressed in collective visits to Belgrade and Sofia, "and these 
trips have a clearly demonstrative nature" [10].

In addition, at that time both Milan Obrenović and Alexander Battenberg left the political arena, and "these happily changed political circumstances equally provide Serbia and Bulgaria with Russia's attention and benevolence". Contemporaries believed that the forgetting of the "Slivnitsa and Pirot memories" would become the basis for that "fruitful organic work that will one day lead to a peaceful defensive alliance of the Slavic states of the Balkan Peninsula" [10].

The media of the Balkan states actively spoke of this alliance as a purely political association. Russian observers noted to the objections of the opposition Bulgarian press about the timeliness and dangers of such a union based on Russia and France, that "for small states, it is necessary to determine in advance which side to take due to known complications". According to Russian observers, this union "is a necessity, which the Balkan states will be forced to resort, sooner or later ", because at that time they represented isolated and weak states, "they can not play any prominent role in the international policy "[10].

\section{Discussion}

In the opinion of the authors of the journal "Vestnik Evropy", the minor Balkan states are, without a doubt, called upon to play a significant role in events related to affairs in the European southeast" [11]. From this point of view, the agreement between Serbia and Bulgaria acquired a special interest, marking the final reconciliation of the two countries: "the long-standing dream of all enlightened patriots of both related neighboring countries" [11].

In this agreement, fixed by the bilateral meeting of Alexander Obrenović with the Bulgarian prince first in Belgrade, and then in Sofia, contemporaries saw there the guarantee of strong bonds between the three Slavic states. The literate people of Serbia believed that only in "a sincere agreement and the rapprochement of the small Balkan states, we can find the correct basis for the defense of their national interests and for countering the aggressive plans on the Balkan peninsula of our "good neighbor" AustriaHungary" [11].

The opposition newspapers of the Balkan states, like the newspaper "Narodnye Prava", tried to prove the 
irrelevance of the Balkan Union, the idea of which was allegedly inspired by Petersburg, or they spoke of the possibility of an alliance, provided Russia would not interfere, either directly or indirectly [10].

According to observers, the Bulgarian newspaper dreamed of nothing less about the Balkan alliance adjacent to the Triple Alliance, but according to observers, the Balkan Union could not do anything without Russia "because it interests in the fate of the Balkan peoples more than other powers" [10]. In addition, Russia took the most active part in the cause of their liberation, and "it would be contrary to common sense if the Slavic peoples made a union apart from it or to the detriment of it". But the truly determinant significance of Russia's participation in this association was due to the fact that only "the Balkan Union under the leadership of Russia can ensure the future of the Slavic states, which can not be done by Austria" [10].

\section{Summary}

Austria-Hungary was afraid of uniting the Slavic countries of any configuration, so it was precisely the
202

"whisperings" of its diplomats and the media that Russian observers and analysts attributed to the constant disagreement between Serbia, on the one hand, and Bulgaria and Montenegro, on the other. According to Russian commentators, Balhausplatz's politicians pursued towards the Balkan states the line that "Russia is the worst enemy, Austria is a devoted and unselfish friend, a strong stronghold of their independence and freedom" [12]. Weakening the influence of Russia, Austria tried as deeply as possible to drive a wedge between the Slavic states, "sow seeds of disagreement and discord between them, exasperate enmity between tribals and bring it to infighting" [12]. The Serbian-Bulgarian war was considered precisely as the result of the Austria-Hungary's activities. While the Slavs were killing each other, Austria withdrew into their hands their political and economic independence.

With the aim of eliminating "dangerous rivalries" from the Balkan states, the unification of which became very real, the Dual Monarchy was forced to conclude an agreement with Russia in 1897, which contained the principle of non-interference. [13] 
The need to prevent possible dangers to the European world led to an agreement with Russia of 1897 that "aims to ensure the elimination of those dangerous rivals that for so many years have produced a heavy stone pressure on our mutual relations and which, as experience has shown, benefited to harm to both powers the strong elements on the Balkan Peninsula". According to A. Golukhovsky, the correctness of the view of "these things" (relations in the Balkans) was the "healing" observance of the status quo principle, which was repeatedly applied and justified itself. Both Austria and Russia need to adhere to the agreements reached, otherwise "the fruits of such a happily reached agreement will be lost and doors and gates will be opened again to risky surprises". All incidents that stood in line on the Balkan peninsula and made it such a "dangerous place" were, in the minister's opinion, lifted by this agreement, thanks to which "the danger of deeper complications was minimized due to the pronounced will of the two most interesting great powers there.

\section{Conclusions}

203

In July 1895, the formation of a new government was entrusted to one of the leaders of the Progressive Party, Stoyan Novaković, but the country continued to face an internal political crisis. The conflict between the parties, coupled with the hostility of the royal dynasties, led Serbia to become a certain pendulum "between the influences of neighboring colossi: here, even as soon as Obrenovićes ceases to sympathize with the nearest neighbor, Karageorgevićes, lodged there on the stage, immediately appear" [14].

Given that Milan Obrenović, the father of the ruling monarch returned to the country became the commanderin-chief of the Serbian army, contemporaries did not surprise that "the directions in Serbia's policy change almost with every high: ministries live no more than six months."

After that, Alexander paid a visit to Rome where he was extremely cordially greeted by the King Umberto I. The same warm meeting between Alexander and the Pope gave rise to rumors about concluding a concordat between Belgrade and Rome: among all European states, Serbia remained the only one where there was no Catholic Bishop (10 thousand Serbian Catholics 
were subordinate to the Croatian ruler Strossmayer).

In October 1897, another Cabinet was headed by a loyal supporter of the regime, Vladan Đorđević. Returning to Belgrade, ex-King Milan Obrenović, who was a behind-the-scenes architect of the new regime, in early 1898 took over as commander-in-chief of the Serbian army. Being in power in the period of 1897-1900, the government of $\mathrm{V}$. Đorđević continued to focus on Austria-Hungary in foreign policy, which was reinforced by the proAustrian position of Alexander Obrenović. It is difficult to judge the degree of influence during this period of his father, the ex-King Milan; obviously, it was not so great, otherwise it is difficult to explain the rather bold statements of King Alexander regarding the unconditional support of Serbia from Austria-Hungary, as happened with his public statement in August 1899, when he stated that "the enemies of Serbia are the enemies of Austria-Hungary" [15], having astonished the experienced diplomats of Vienna.

On the night of May 29, 1903, the officers-conspirators, being dissatisfied with the entire policy of Alexander Obrenović, broke into the royal palace and brutally murdered King Alexander and his wife Draga [16]. The coup d'état was favorably received in Serbia, and after a few days the Assembly rebuilt the Constitution of 1888 and elected Petar Karageorgiević, a representative of another Serbian dynasty, as the new king. [17]

\section{Acknowledgements}

The work is performed according to the Russian Government Program of Competitive Growth of Kazan Federal University.

\section{References}

B. Jelavich, "History of the Balkans", Cambridge, Vol. II, pp. 476, 1983.

\section{J. J. Alcock, "Explaining Yugoslavia", London, pp. 499, 2000.}

V.E. Tumanin, M.Z. Galiullin, D.R. Sharafutdinov, "1889-1893 Regency in Serbia as the Russian Society Saw It", International Journal of Humanities and Cultural Studies, July, pp. 81-87, 2016. "Political Chronicle", Severny Vestnik, No. 5, pp. 99-118, 1893. 
"Foreign Review", Vestnik Evropy, Vol.

5, pp. 797-810, 1893.

"Political Chronicle", Severny Vestnik, No. 6, pp. 103-120, 1894.

"Political Chronicle", Severny Vestnik, No. 10, pp. 102-119, 1894.

"Political Review", Russky Vestnik, No. 10, pp. 310-323, 1894.

"Political Review", Russky Vestnik, No. 11, pp. 313-323, 1894.

"Political Chronicle", Nablyudatel', No. 7, pp. 37-51, 1896.

"Foreign Review", Vestnik Evropy, Vol. 6, pp. 800-814, 1896.

"Political Review", Russky Vestnik, No. 9, pp. 358-366, 1896.

B. Jelavich, "Russia's Balkan Entanglements: 1806-1914”, Cambridge, pp. 287, 2004.

"Political Chronicle", Severny Vestnik, No. 12, pp. 95-117, 1896.
G. Stores, "Politics as Development. The Emergence of Political Parties in Nineteenth-Century Serbia", DurhamLondon, pp. 400, 1990.

H. Sundhaussen, "Geschichte Serbiens: 19-21. Jahrhundert", Wien-Köln, pp. 398, 2007.

M.B. Petrovich, "A History of Modern Serbia 1804-1918”, New York-London, Vol. II, pp. 635, 1976 